DOI: https://doi.org/10.15688/jvolsu4.2019.1.14

UDC 94(37).08

Submitted: 16.04 .18

LBC 63.3(0)32

Accepted: 04.07.18

\title{
A MILITARY UNIT OF THE CELTAE (THE CELTS) AND SOME PECULIARITIES OF LATE ROMAN MILITARY TITLES IN THE ${ }^{\mathrm{TH}}$ C. AD
}

\author{
Evgeniy A. Mekhamadiev \\ Saint Petersburg State University, Saint Petersburg, Russian Federation
}

\begin{abstract}
Introduction. The Late Roman administration used to practice many ways of interrelations with the Barbarian tribes, but modern scholarship tended and tends to pay main attention to external perspectives of interrelations, i.e. issues of barbaric invasions and methods of their accomodation within the Roman territory. In contrast, modern scholarship pays little attention to internal perspectives of interrelations, and partly, to one of the point of internal interrelations, which is strictly under consideration in this paper. This point is a meaning of official titles, which Roman administration gave to military detachments composed of the German warriors. Basing on evidence about an elite military unit of the Celtae and the name Celtae itself, the author aims to regard peculiarities of Late Roman military nomenclature and to trace how this nomenclature reflected an official political ideology of imperial supremacy, a system of Romans' views and opinions about the Barbarians. Methods. The author studies these matters by comparing the evidence of Ammianus Marcellinus, Greek dedicatory inscription from the city of Stobi (the province of Macedonia) and some panegyrics (the so-called Latin panegyrics, a speech of Julian the Apostate in honor of the Emperor Constantius II and the "Thanksgiving oration" of a prominent Gallic rhetorician Ausonius for the Emperor Gratianus). The author traces how

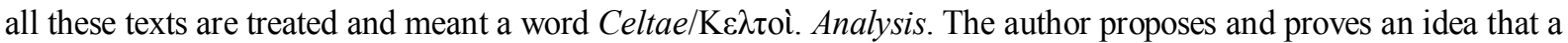
military unit of the Celtae was composed of the captive Alamanni presumably between the reign of the Emperor Diocletian (284-305) and 351/352. Results. Having based on the evidence enumerated above, the author concluded that the the unit of the captive Alamanni received an official title of Celtae because the Romans used to name the German captives as more ancient people, over which the Roman won decisive and brilliant victories in previous times. This naming practice was one of the persistent peculiarities of the Late Roman military nomenclature and records management working.

Key words: palace auxiliary detachment, the Celtae, the Alamanni, the Germans, panegyrics, Theodosius the Elder, the Rhine frontier.

Citation. Mekhamadiev E.A. A Military Unit of the Celtae (the Celts) and Some Peculiarities of Late Roman Military Titles in the $4^{\text {th }} \mathrm{C}$. AD. Vestnik Volgogradskogo gosudarstvennogo universiteta. Seriya 4, Istoriya. Regionovedenie. Mezhdunarodnye otnosheniya [Science Journal of Volgograd State University. History. Area Studies. International Relations], 2019, vol. 24, no. 1, pp. 165-173. (in Russian). DOI: https://doi.org/10.15688/jvolsu4.2019.1.14
\end{abstract}

\section{ВОЙСКОВОЕ ПОДРАЗДЕЛЕНИЕ СЕLТАЕ («КЕЛЬТЫ») И НЕКОТОРЫЕ ОСОБЕННОСТИ ПОЗДНЕРИМСКОЙ ВОЕННОЙ ТЕРМИНОЛОГИИ В IV ВЕКЕ}

\author{
Евгений Александрович Мехамадиев
}

Санкт-Петербургский государственный университет, г. Санкт-Петербург, Российская Федерация 
Аннотация. Введение. Позднеримская военная администрация выработала множество методов взаимодействия с варварскими племенами, в основном с германцами, но исследовательская литература традиционно уделяла и уделяет главное внимание внешним аспектам взаимодействия, то есть вторжениям варваров на территорию империи и методам их расселения. И наоборот, мало внимания уделяется аспекту внутреннего взимодействия, и в частности, одному из процессов этого вида взаимодействий - значению тех официальных наименований, которые римская администрация присваивала войсковым подразделениям, навербованным из представителей германских племен. На примере истории войскового подразделения Celtae и самого названия данного подразделения, которое обладало элитным рангом дворцовой ауксилии, автор ставит целью рассмотреть особенности позднеримской военной терминологии, выявить, как данная терминология отражала официальную политическую идеологию имперского величия, систему представлений римлян о варварах. Meтодbl. Автор проводит свой анализ на основе сопоставления сведений Аммиана Марцеллина, греческой посвятительной надписи из Стоби (провинция Македония) и сообщений панегириков (так называемые Латинские панегирики, речь Цезаря Юлиана в честь императора Констанция II и «Благодарственная речь» Авсония в честь императора Грациана). Автор прослеживает, какой смысл все перечисленные

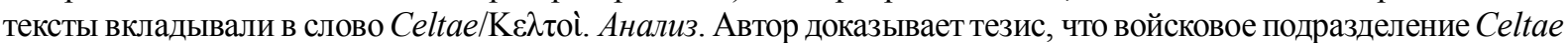
было сформировано из пленных аламаннов в период между эпохой Тетрархии (284-305) и 351/352 годами. Результаты. На основе рассмотренного материала автор пришел к выводу, что эти аламанны получили наименование Celtae в связи с тем, что римляне часто называли германских пленников именами более древних народов, с которыми Римское государство воевало в предшествующие периоды своей истории и неизменно одерживало над ними блистательные и решительные победы. В этой практике состояла одна их характерных особенностей позднеримской военной терминологии и делопроизводственной практики.

Ключевые слова: дворцовая ауксилия, Кельты, аламанны, германцы, панегирики, Феодосий Старший, рейнская граница.

Цитирование. Мехамадиев Е. А. Войсковое подразделение Celtae («Кельты») и некоторые особенности позднеримской военной терминологии в IV веке // Вестник Волгоградского государственного университета. Серия 4, История. Регионоведение. Международные отношения. - 2019. - Т. 24, № 1. - С. 165-173. DOI: https://doi.org/10.15688/jvolsu4.2019.1.14

Введение. Как правило, современная исследовательская литература, посвященная взаимоотношениям варваров (преимущественно германских племен) и поздней Римской империи в IV-V вв., в основном рассматривает внешний аспект взимодействий - миграции варваров на территорию империи, методы их расселения, маршруты завоеваний и взаимовлияние варваров и римлян друг на друга в плане развития общества и культуры. Именно этот внешний аспект представлен в двух масштабных исследованиях У. Гоффарта и Г. Хальсалла, а также в серии статей, изданных этими же авторами, уже долгое время ведущими друг с другом интенсивную полемику [12-16]. И наоборот, значительно меньше внимания уделяется внутреннему аспекту взаимодействия, точнее, одному из процессов этого вида взаимодействия. Мы имеем в виду формирование из представителей германских племен регулярных войсковых подразделений позднеримской армии. Важную роль при создании подобных боевых отрядов, этнических по своему кадровому составу, играло официальное наименование, которое получал отряд, навербованный из германцев, пленных или свободных, вне зависимости от их положения. Название, которое римская администрация присваивала тому или иному этническому подразделению, зачастую не имело никакого отношения к кадровому составу самого подразделения, никак не отражало этническое происхождение воинов подразделения. Вместе с тем подобные названия весьма отчетливо отражали официальную политическую идеологию империи, те представления римлян о варварах, которые были распространены не только среди рядового населения империи, но и среди ее политической элиты, бюрократического аппарата.

В данной статье мы рассматриваем процесс внутреннего взаимодействия варваров и римлян на примере названия одного из элитных войсковых подразделений - так называемой дворцовой ауксилии Celtae («Кельты»). Несмотря на тот факт, что само подразделение занимало привилегированное положение в позднеримской военной иерархии, тем не менее, его название отражало не статус войсковой части как таковой, но особенности позднеримского имперского мышления и пропаган- 
ды, то есть, скорее, процессы, происходившие в области политической идеологии.

Методы и материалы. Главный метод, примененный в данном исследовании, - сопоставление наименований (этнонимов) Celtae/

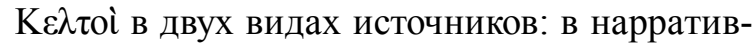
ных (классические большие «истории», а также панегирики) и эпиграфических (надписи). Мы сравниваем тот смысл, который вклады-

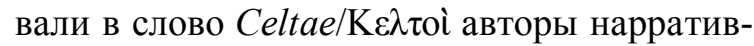
ных источников и составители надписей, выявляем различия в содержании по текстам нарративных источников и надписей. На наш взгляд, данная методика позволяет определить, как те или иные этнонимы, в том числе

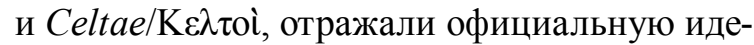
ологию римского имперского величия, систему взглядов и представлений римлян о варварах. На основе проведенного сопоставления мы сможем сделать выводы о кадровом составе, времени учреждения и этническом происхождении войскового отряда Celtae. Полагаем, что подобная методика дает возможность уточнить особенности позднеримской военной терминологии, связанной с использованием различных этнонимов; с помощью указанного метода мы можем в значительной мере уточнить этнографический лексикон панегириков, когда их авторы упоминали те или иные племена.

Мы обратились к таким текстам, как «Деяния» (Res gestae) Аммиана Марцеллина и «Новая история» Зосима (большие «истории», созданные по канонам классического античного историописания), панегирики Цезаря Юлиана (будущего императора Юлиана Отступника) в честь императора Констанция II и Децима Магна Авсония (прославленного галльского ритора) в честь императора Грациана, а также греческую посвятительную надпись из города Стоби в провинции Македония.

Касательно историографии подчеркнем, что в первую очередь мы учитывали исследования и выводы М. Коломбо, активно изучавшего этнонимию варварских племен в труде Аммиана Марцеллина, а также работы Д. Гюниха, Р. Шарфа, Л. Варади, М.П. Шпайделя, Б. Блекманна и Ф. Ранса.

Анализ. В 378 г. германское племя лентиензов, жившее на границе римской провинции Реция, попыталось перейти Рейн и вторгнуться в Галлию, но, как сообщает Аммиан Марцеллин, нападение германцев было отбито двумя войсковыми подразделениями - Кельтами (Celtae) и Петулантами (Petulantes), которые на тот момент выполняли службу на рейнском фронте («Кельты, которые располагались поблизости вместе с Петулантами, не без ущерба для себя нанесли им (то есть германцам. $-E$. M.) тяжелый удар и с помощью своих крепких воинов обратили их (то есть германцев. $-E$. M.) в бегство» - quos tendentes prope cum Petulantibus Celtae non sine sui iactura afflictos graviter adultis viribus averterunt - [3, p. 182183 -Amm. XXXI. 10. 4]).

Впоследствии, как сообщает Аммиан, император Грациан, правивший в то время в западных провинциях империи, выступил против германцев в большой карательный поход, в результате вблизи города Аргенторат (современный Страсбург) состоялось крупное сражение, в котором римляне разгромили аламаннов и остановили их продвижение в земли Галлии. Судя по всему, войсковая группировка, в состав которой входили два названных выше подразделения, находилась под командованием комита обеих Германий (comes per utramque Germaniam) Нанниена, именно этому офицеру Грациан поручил провести боевую экспедицию против аламаннов у Аргентората - как предположил М. Коломбо, к 378 г. Нанниен занимал именно должность комита обеих Германий, то есть возглавлял экспедиционные (полевые, походные) войска германских провинций империи [7, р. 209].

Следуя логике, можем предположить, что Кельты и Петуланты представляли собой отряды неболышой региональной экспедиционной армии, оборонявшей рейнский фронт от германских набегов, Аммиан называет данную армию императорской гвардией («доспехи императорской гвардии, блистающие яркостью и цветами золота» - arma imperatorii comitatus auro colorumque micantia claritudine - [3, p. 184 Amm. XXXI. 10. 14]). Соответственно, оставляя за рамками данной статьи вопрос об этническом происхождении и кадровом составе отряда Петулантов, обратимся к истории возникновения и функциям подразделения Кельтов, упоминающемуся в труде Аммиана Марцеллина. Главный сюжет, которому мы уделим внимание, - проблема этнического про- 
исхождения отряда Кельтов, кто на самом деле скрывался под наименованием Celtae?

Прежде всего подчеркнем, что подразделения Кельтов и Петулантов упоминаются у Аммиана и ранее, применительно к событиям 360 г. - Аммиан называет их вспомогательными отрядами и перечисляет в составе войск, находившихся под командованием Цезаря Юлиана (будущего императора) в Галлии (auxiliares milites... cumque Petulantibus Celtas [2, p. 188 - Amm. ХХ. 4. 2]). Слова Аммиана недвусмысленно свидетельствуют, что оба войсковых подразделения принадлежали к рангу дворцовых ауксилий (auxilia palatina), то есть входили в состав императорской гвардии и размещались непосредственно в резиденции императора (очевидно, в Трире, где на тот момент располагалась ставка Грациана). В этом смысле мы считаем целесообразным обратиться непосредственно к сведениям самого Юлиана, точнее - к его панегирику в честь императора Констанция II, правившего империей в 337-361 годах. Данный панегирик, как полагают исследователи, был написан в 356 году [24, p. 20].

В своем панегирике Юлиан, обращаясь к Констанцию II, отмечает, что «Кельты и Галаты <...> покорились нам вопреки своей воле и были зачислены в отряды войска, они поставляли доблестные подразделения, которые набирали твои (то есть Констанция II. E. M.) предки и отец. Наслаждаясь великим миром и благами этого мира, который дал им землю для богатства и изобилия людей, они предоставили твоим братьям (возможность) набирать многих воинов (в армию)» (Кєлтоі

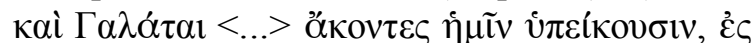

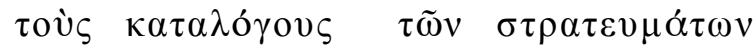

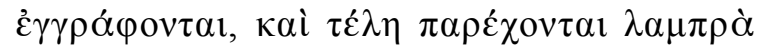

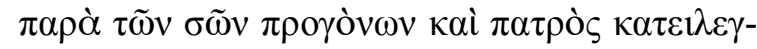

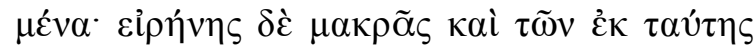

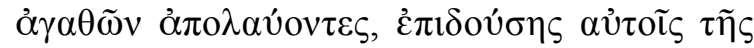

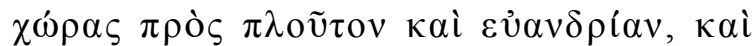

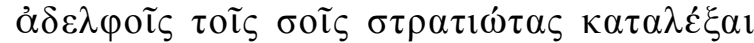
$\pi \circ \lambda \lambda$ où $\varsigma \alpha \rho \rho \varepsilon \sigma \chi \circ \nu \tau o$ ([23, p. 88 - Jul. Or. I. 34 $\mathrm{c}-\mathrm{d}$, ed. W.C. Wright]).

М.П. Шпайдель предположил, что под «кельтами и галатами» (Кє о которых говорит Юлиан, на самом деле следует понимать не галло-римское население Галлии, а зарейнских германцев, с которыми воевали правители-тетрархи (Диоклетиан, Максимиан Геркулий и Констанций Хлор), правившие в 284-305 гг., и Константин I Великий (306-337 гг.), поскольку грекоязычные авторы позднеримского времени часто называли германцев галлами, кельтами или галатами [22, p. 134]. Действительно, у нас нет сомнений, что «предками» Констанция II, о которых говорит Юлиан, были Цезарь Констанций Хлор, отец Константина Великого и дед Констанция II, а также соправители Констанция Хлора - Диоклетиан, Максимиан Геркулий и Цезарь Максимин Галерий.

Очевидно, Юлиан имел в виду пленных германцев, которые были принудительно распределены среди регулярных римских войсковых соединений на рейнской границе, эти пленники, судя по всему, пополнили численность легионов, ал и когорт, оборонявших рейнский фронт. Таким образом, совершенно ясно, что пленники-германцы пополнили римскую пограничную армию на Рейне в результате успешных карательных экспедиций, которые правители-тетрархи провели против нескольких германских племен, главным образом франков и аламаннов, в период 284-305 годов. Следовательно, к середине 350-х гг., то есть к тому времени, когда Юлиан написал свой панегирик, в римской армии сложилась устойчивая традиция именовать германцев (при этом именно тех, с которыми империя воевала) кельтами, галлами или галатами, то есть старыми, давно и хорошо известными для римлян этнонимами. Но это же предположение закономерно рождает и новый вопрос: какое германское племя сформировало отряд под названием «Кельты» (Celtae), какие германские племенные союзы скрывались под этим наименованием - франки или аламанны?

В связи с поставленным вопросом необходимо обратиться к ценному эпиграфическому документу, а именно - к греческой посвятительной надписи из города Стоби (в римский период - провинция Македония), воздвигнутой в честь Феодосия Старшего, западноримского полководца и политического деятеля, отца будущего императора Феодосия I Великого, который правил в восточных провинциях империи в 379-395 годах. Данная надпись была опубликована еще в 1931 г. (AE. 1931. 53) Р. Эггером, тем не менее, пос- 
леднее по времени издание надписи было предложено в каталоге Д. Фесселя «Сборник христианских надписей Македонии с III по VI в.» (Recueil des inscriptions chrétiennes de Macédoine du $\mathrm{III}^{\mathrm{e}}$ au $\mathrm{VI}^{\mathrm{e}}$ siècle), цитируем текст по чтению Д. Фесселя [10, p. 228, no. 273]:

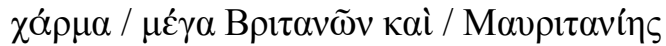

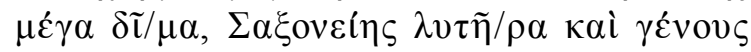

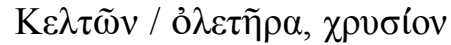

«великая радость для британцев и великий страх для Мавритании, (в честь) освободителя Саксонии и разрушителя народа кельтов золотой...».

Первоиздатель надписи, Р. Эггер, идентифицировал персонажа, которому посвящена надпись, именно с Феодосием Старшим [9, S. 11], позиция Р. Эггера была поддержана и всеми последующими исследователями, которые обращались к тексту надписи [20, p. 54; 10 , p. 229; 18, p. 232-233], опять же, Р. Эггер первым определил, что под фразой $\gamma \varepsilon ́ v o v \varsigma$

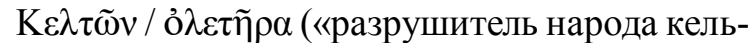
тов») следует понимать военные кампании, проведенные против аламаннов [9, S. 17]. Мы в равной мере не оспариваем идентификацию, предложенную Р. Эггером, мы считаем ее полностью аргументированной, другой вопрос, что в таком случае составитель надписи определенно допустил топографическую ошибку, и, судя по всему, данная ошибка была сознательной, она отражала особенности официальной пропаганды имперского величия во второй половине IV века.

Галльский ритор Пакат, написавший и торжественно огласивший свой панегирик в честь Феодосия I Великого в Риме в 389 г., уделил много внимания и карьере Феодосия Старшего, ритор посвятил данному сюжету пространную главу своей речи, среди военных кампаний, которые провел Феодосий Старший, Пакат упоминает и боевые действия против аламаннов («Но перед моим взором предстанут все аламанны, отогнанные в свои nустыни...» - Compulsus in solitudines avias omnis Alamannus [17, p. 649 - Pan. Lat. XII (2). 5. 2]) ${ }^{1}$. Как детально проследил М. Коломбо, под фразой Паката omnis Alamannus следует понимать кампанию против аламаннов, которую Феодосий Старший успешно провел в 370 г. на границе с Рецией, в основном боевые действия развернулись в долине реки
Неккар на юго-западе современной Германии, где в то время обитали аламанны [6, p. 234; 5 , p. 153-154, 157].

Примечательно, что аламанны - единственный народ, живший за Рейном, который упоминается у Паката среди противников Феодосия Старшего. Все остальные противники римского генерала размещались за пределами рейнского фронта (сарматы на Дунае ${ }^{2}$, саксы на берегу Северного моря, более известные все же по морским сражениям, скотты в Британии и мавры в северной Африке).

Следовательно, мы можем предположить, что к началу 370-х гг. римские авторы (как греческие, что видно из сведений надписи, так и латинские) вполне устойчиво именовали аламаннов кельтами, то есть присваивали германцам этноним, в культурно-историческом плане относящийся скорее к местному галло-римскому населению. Конечно же, совершенно очевидно, что Феодосий Старший не был разрушителем собственно племен кельтов, то есть местного населения Галлии, он не воевал против местных жителей данного региона, Феодосий интенсивно боролся с набегами аламаннов, которых наши источники называют кельтами. В этом случае возникает новый закономерный вопрос - почему римские авторы предпочитали называть аламаннов кельтами, какими мотивами руководствовались римские историки и публицисты?

Для ответа на этот вопрос приведем пример с другим позднеримским войсковым подразделением - Cimbriani («Кимвры»). Это подразделение, обладавшее элитным рангом дворцового легиона (legio palatina), конечно же, получило свое название в честь германского племени кимвров, над которыми еще в 102 г. до н. э. римляне во главе со своим знаменитым полководцем Гаем Марием одержали решительную и блистательную победу. В исследовании, посвященном отряду Cimbriani, Р. Шарф убедительно доказал, что этот легион, в свою очередь, восходит к пограничному гарнизону, размещавшемуся в крепости Cimbrianis на территории нижней Паннонии. По мнению Р. Шарфа, название Cimbriani связано именно с топонимом Cimbrianis [21, p. 179-180], в то время как сама крепость Cimbrianis определенно получила свое название от племени кимвров. Более того, кимвры упоминаются в од- 
ном из писем Иеронима Стридонского, который, рассказывая о крупном вторжении германских племен в Галлию зимой 406/407 гг., отмечает, что «сейчас (земли) самой Испании ежедневно трепещут в ожидании своей гибели, вспоминая вторжение кимвров» (ipsae Hispaniae iam iamque periturae cotidie contremescunt recordantes inruptionis Cymbricae - [19, p. 92, 1. 15-17 - Hieronymus, Ep. 123. 15]). Важно подчеркнуть, что в содержательно-смысловом плане Иероним сравнивает вторжение вандалов, франков, аламаннов, свевов и других германских племен, прорвавших и разрушивших рейнскую границу империи в 406/407 гг., с вторжением кимвров, которые перешли альпийские рубежи, но были полностью разбиты в 102 г. до нашей эры.

Следовательно, дворцовый легион Cimbriani, существовавший в позднеримской армии, судя по всему, был назван в честь кимвров как раз по той причине, что этот легион состоял из германцев, а значит, в случае с легионом наименование Cimbriani отражало особенности позднеримской имперской пропаганды. На наш взгляд, такое наименование могли получить только пленные германцы. Римская администрация присвоила им данное наименование в память о древней и славной победе над другим германским племенем, которое когда-то было полностью разгромлено римлянами. Эта победа осталась в памяти римлян как символ неувядающей славы римского оружия.

Тем не менее позднеримская администрация выработала и другую практику формирования военной терминологии, то есть наименований отдельных войсковых подразделений. Не так давно Д. Гюних предположил, что войсковое подразделение в ранге дворцовой ауксилии (auxilia palatina) под названием Brisigavi было создано и навербовано не из аламаннов, живших вблизи современного города Брайсгау на юго-западе Германии (как полагала вся предшествующая историография), но из местного галло-римского населения, точнее - из жителей сельского округа под названием mons Brisiacus, этот округ получил название в честь горы, возле которой он располагался. Соответственно, как полагает Д. Гюних, имя Brisigavi представляет собой не германский этноним, а галльский топоним кельтского происхождения [11, S. 208-209]. Но, на наш взгляд, не исключен и другой вариант: войсковой отряд Brisigavi был сформирован из аламаннов, попавших в плен в результате римских карательных экспедиций в районе Брайсгау, но получил свое наименование в честь того небольшого региона, который располагался в пределах Галлии, то есть уже на римской территории.

И наконец, источники позволяют нам выделить третий метод присвоения военных наименований, в частности, победной титулатуры императоров - галльский ритор и политический деятель Авсоний в панегирике императору Грациану (375-383 гг.) восторженно отмечает: «Я назвал бы (тебя) (то есть Грациана. $E$. M.) Германским, поскольку племена сдаются в плен, Аламаннским, поскольку ты ведешь пленников в триумфальном шествии, и Сарматским, поскольку ты побеждаешь и милуешь» (vocarem Germanicum deditione gentilium, Alamannicum traductione captorum, vincendo et ignoscendo Sarmaticum - [8, p. $216-$ Ausonius, Gratiarum actio, II. 8]).

Как показал Л. Варади, титул Sarmaticus в труде Авсония подразумевал военные кампании, развернувшиеся на территории Паннонии и других провинций Иллирика, то есть в землях по верхнему и среднему течению Дуная [25, S. 179-181]. Но в таком случае необходимо подчеркнуть, что император Грациан, которому Авсоний посвятил свою торжественную речь, не воевал в пределах Иллирика. В данном регионе воевал Феодосий I, император восточных провинций империи. В свою очередь, этот факт позволяет заключить, что под наименованием Sarmaticus у Авсония скрывались не сарматы, а готы, поскольку Феодосий боролся именно с готами. Авсоний же, желая всемерно восхвалить Грациана, просто приписал ему военные победы, одержанные Феодосием. На наш взгляд, при выборе победных титулов Авсоний руководствовался принципами и мотивами официальной римской имперской пропаганды. Галльский ритор предпочел назвать готов старым и более известным этнонимом, то есть сарматами, поскольку ранее, до восшествия Грациана на императорский престол, римляне всегда одерживали уверенные победы над племенами сарматов. 
Результаты. Таким образом, мы можем выделить три основных механизма формирования позднеримской военной терминологии, то есть присвоения официальных наименований отдельным войсковым подразделениям. Естественно, эти механизмы относятся только к подразделениям этнического характера, то есть к отрядам, навербованным из представителей какого-либо племени, если данное племя жило за пределами римских границ: 1) римская администрация создавала из пленных германцев обособленный этнический боевой отряд, но наделяла этот отряд именем той местности, которая размещалась уже в пределах самой империи, была частью римских владений (пример с подразделением Brisigavi); 2) пленные германцы получали наименование в честь другого, более древнего племени или народа, с которыми ранее римляне вели крупные и успешные войны и над которыми Рим всегда одерживал блистательные победы (пример с легионом Cimbriani); 3) римские авторы могли назвать какое-либо новое германское племя, только недавно выступившее против империи, именем более старого противника, который был лучше известен образованному читателю, и это был тот противник, над которым в предшествующие периоды империя всегда и неизменно одерживала военные победы (этот способ применялся при перечислении официальных императорских победных титулов).

В случае с подразделением (дворцовой ауксилией) Кельты (Celtae) мы скорее можем говорить о втором механизме: аламанны, против которых римляне проводили интенсивные военные кампании, в ходе одной из этих кампаний были разгромлены, захвачены в плен и принудительно переселены в Галлию, то есть в пределы империи. Впоследствии римская администрация сформировала из этих пленников обособленное этническое войсковое подразделение, которое получило наименование Celtae. Мы полагаем, что данное наименование отражало римскую имперскую пропаганду, тем самым пленные аламанны логично «превратились» в местных граждан империи, то есть в кельтов. Римляне прекрасно помнили, что когда-то, еще в эпоху ранней Республики, кельты, или галлы, были военными противниками Рима. Они потерпели пораже- ния, были завоеваны и присоединились к Римскому государству, соответственно, органично превратились из внешних врагов Рима в составную внутреннюю часть его населения. С учетом сведений Аммиана Марцеллина, сообщающего, что подразделение Кельтов уже существовало к 360 г., мы можем предположить, что оно было сформировано до этой даты. Самое раннее - в эпоху Тетрархии или Константина I Великого, самое позднее - по результатам военных кампаний императора Констанция II, сына Константина I, против узурпатора Магненция в 351/352 г., когда Констанцию сдались в плен многие германцы, поддерживавшие узурпатора [4, S. 93].

\section{ПРИМЕЧАНИЯ} [1, c. 409].

${ }^{1}$ Русский перевод цитируется по изданию:

${ }^{2}$ Как заметил еще Р. Эггер, фраза о сарматax - сознательная ошибка Паката, галльский ритор намеренно причислил к военным достижениям Феодосия Старшего победу, которую на самом деле одержал его сын Феодосий в 374 г., тогда Феодосий-младший занимал еще должность дукса Мезии верхней (первой). См.: [9, S. 18].

\section{СПИСОК СОКРАЩЕНИЙ}

CSEL - Corpus Scriptorum Ecclesiasticorum Latinorum. Vindobonnae, 1889.

RÉMA - Revue des Études militaires anciennes. Paris, 2004.

$Z P E$ - Zeitschrift für Papyrologie und Epigraphik. Bonn, 1967.

\section{СПИСОК ЛИТЕРАТУРЫ}

1. Латинские панегирики / вступ. ст., пер. и коммент. И. Ю. Шабаги. - М. : Ун-т Дмитрия Пожарского, 2016. - 672 c.

2. Ammiani Marcellini rerum gestarum libri qui supersunt / ed. W. Seyfarth. - Vol. I : libri XIV-XXV. Lipsiae : Teubner, 1978. $-380 \mathrm{p}$.

3. Ammiani Marcellini rerum gestarum libri qui supersunt / ed. W. Seyfarth. - Vol. II : libri XXVIXXXI. - Lipsiae : Teubner, 1978. -248 p.

4. Bleckmann, B. Die Schlacht von Mursa und die zeitgenössische Deutung eines spätantiken Bürgerkrieges / B. Bleckmann // Gedeutete Realität 
Krisen, Wirklichkeiten, Interpretationen (3.-6. Jh. n. Chr.) / Hrsg. von H. Brandt. - Stuttgart : Franz Steiner Verlag, 1999.-S. 47-101.

5. Colombo, M. Due note storiche e letterarie sui libri XXVIII-XXX di Ammiano Marcellino / M. Colombo // Philologus. - 2006. - Bd. 150/1. P. 149-174.

6. Colombo, M. La carriera militare di Teodosio il Vecchio. Il soprannome trionfale Francicus maximus di Valentiniano I e la tendenziosità storiografica di Ammiano Marcellino/ M. Colombo // Historia. -2017. Bd. 66/2. - P. 228-256.

7. Colombo, M. Una revisione critica di Amm. 31.10 / M. Colombo // Acta Antiqua Academiae Scientiarum Hungaricae. - 2007. - Vol. 47/2. - P. 203-216.

8. Decimi Magni Ausonii Burdigalensis opuscula / ed. S. Prete. - Lipsiae : Teubner, 1978. -417 p.

9. Egger, R. Die Erste Theodosius / R. Egger // Byzantion. - 1929/1930. - Vol. 5. - S. 9-32.

10. Feissel, D. Recueil des inscriptions chrétiennes de Macédoine du $\mathrm{III}^{\mathrm{e}}$ au $\mathrm{VI}^{\mathrm{e}}$ siècle / D. Feissel. - Paris : de Boccard, 1983. - 290 p.

11. Geuenich, D. Die alemannischen "Breisgaukönige" Gundomadus und Vadomarius / D. Geuenich // Historia archaeologica. Festschrift für Heiko Steuer zum 70. Geburtstag / Hrsg. von S. Brather, D. Geuenich. - Berlin; N. Y. : De Gtuyter, 2009. - S. 205-216.

12. Goffart, W. Administrative Methods of Barbarian Settlement in the Fifth Century: The Definitive Account / W. Goffart // Gallien in Spätantike und Frühmittelalter: Kulturgeschichte einer Region / Hrsg. von St. Diefenbach. - Berlin : De Gruyter, 2013. P. 45-58.

13. Goffart, W. Barbarian Tides. The Migration Age and the Later Roman Empire / W. Goffart. Philadelphia : University of Pensilvania Press, 2006.$372 \mathrm{p}$.

14. Goffart, W. The Technique of Barbarian Settlement in the Fifth Century: A Personal, Streamlined Account with Ten Additional Comments / W. Goffart // Journal of Late Antiquity. - 2010. Vol. 3/1. - P. 65-98.

15. Halsall, G. Barbarian Migrations and the Roman West, 376-568 / G. Halsall. - Cambridge : Cambridge University Press, 2007. - 591 p.

16. Halsall, G. The Technique of Barbarian Settlement in the Fifth Century: A Reply to Walter Goffart / G. Halsall // Journal of Late Antiquity. - 2010. Vol. 3/1. - P. 99-112.

17. In Praise of Later Roman Emperors. The Panegyrici Latini. Introdaction, Translation and Historical Commentary with the Latin Text of R. A. B. Mynors / ed. C. E. V. Nixon, B. S. Rodgers. Berkeley; Los Angeles; Oxford : University of California Press, 1994. - 735 p.
18. Rance, Ph. Epiphanius of Salamis and the Scotti: New Evidence for Late Roman - Irish Relations / Ph. Rance // Britannia. - 2012. - Vol. 43. - P. 227-242.

19. Sancti Eusebii Hieronymi Epistulae. Pars III: epistulae CXXI-CLIV / Rec. I. Hilberg. - Vindobonnae : F. Tempsky, 1918. -368 p. - (CSEL 56).

20. Sanctis, D., de. Ancora sul padre dell'imperatore Teodosio / D. de. Sanctis // Rivista di Filologia e d'istruzuione classica. - 1934. - N. S. Ann. № 12 (62). - P. 52-54.

21. Scharf, R. Die Spätantike Truppe der Cimbriani / R. Scharf// ZPE. - 2001. - Bd. 135. - S. 179-184.

22. Speidel, M. P. The Four Earliest Auxilia Palatina / M. P. Speidel // RÉMA. - 2004. - Vol. 1. P. 133-146.

23. The Works of the Emperor Julian with an English Translation by W. C. Wright. - Vol. I. - L. : William Heinemann, 1913. $-510 \mathrm{p}$.

24. Tougher, Sh. Reading between the Lines: Julian's First Panegyric on Constantius II / Sh. Tougher / Emperor and Author: The Writings of Julian the Apostate / ed. by N. Baker-Brian and Sh. Tougher--Swansea : The Classical Press of Wales, 2012. - P. 19-34.

25. Varady, L. Pannonica Ergänzende Notizen zum letzten Jahrhundert / L. Varady // Bonner Jahrbücher. 1990. - Bd. 190. - S. 175-200.

\section{REFERENCES}

1. Shabagi I.Yu., ed. Latinskie panegiriki [The Latin Panegyrics]. Moscow, Universitet Dmitriya Pozharskogo Publ., 2016. 672 p.

2. Seyfarth W., ed. Ammiani Marcellini rerum gestarum libri qui supersunt. Vol. I: libri XIV-XXV. Lipsiae, Teubner, 1978. 380 p.

3. Seyfarth W., ed. Ammiani Marcellini rerum gestarum libri qui supersunt. Vol. II: libri XXVI-XXXI. Lipsiae, Teubner, 1978. 248 p.

4. Bleckmann B. Die Schlacht von Mursa und die zeitgenössische Deutung eines spätantiken Bürgerkrieges. Brandt von H., ed. Gedeutete Realität Krisen, Wirklichkeiten, Interpretationen (3.-6. Jh. $n$. Chr.). Stuttgart, Franz Steiner Verlag, 1999, pp. 47-101.

5. Colombo M. Due note storiche e letterarie sui libri XXVIII-XXX di Ammiano Marcellino. Philologus, 2006, vol. 150/1, pp. 149-174.

6. Colombo M. La carriera militare di Teodosio il Vecchio. Il soprannome trionfale Francicus maximus di Valentiniano I e la tendenziosita storiografica di Ammiano Marcellino. Historia, 2017, vol. 66/2, pp. 228-256.

7. Colombo M. Una revisione critica di Amm. 31.10. Acta Antiqua Academiae Scientiarum Hungaricae, 2007, vol. 47/2, pp. 203-216.

8. Prete S., ed. Decimi Magni Ausonii Burdigalensis opuscula. Lipsiae, Teubner, 1978. 417 p. 
9. Egger R. Die Erste Theodosius. Byzantion, 1929/1930, vol. 5, pp. 9-32.

10. Feissel D. Recueil des inscriptions chrétiennes de Macédoine du IIIe au VIe siècle. Paris, de Boccard, 1983. 290 p.

11. Geuenich D. Die alemannischen "Breisgaukönige" Gundomadus und Vadomarius. Brather von S., Geuenich D., eds. Historia archaeologica. Festschrift für Heiko Steuer zum 70. Geburtstag. Berlin; New York, De Gtuyter, 2009, pp. 205-216.

12. Goffart W. Administrative Methods of Barbarian Settlement in the Fifth Century: The Definitive Account. Diefenbach von St., ed. Gallien in Spätantike und Frühmittelalter: Kulturgeschichte einer Region. Berlin, De Gruyter, 2013, pp. 45-58.

13. Goffart W. Barbarian Tides. The Migration Age and the Later Roman Empire. Philadelphia, University of Pensilvania Press, 2006. 372 p.

14. Goffart W. The Technique of Barbarian Settlement in the Fifth Century: A Personal, Streamlined Account with Ten Additional Comments. Journal of Late Antiquity, 2010, vol. 3/1, pp. 65-98.

15. Halsall G. Barbarian Migrations and the Roman West, 376-568. Cambridge, Cambridge University Press, 2007. 591 p.

16. Halsall G. The Technique of Barbarian Settlement in the Fifth Century: A Reply to Walter Goffart. Journal of Late Antiquity, 2010, vol. 3/1, pp. 99-112.
17. Nixon C.E.V., Rodgers B.S., eds. In Praise of Later Roman Emperors. The Panegyrici Latini. Introdaction, Translation and Historical Commentary with the Latin Text of R. A. B. Mynors. Berkeley; Los Angeles; Oxford, University of California Press, 1994. $735 \mathrm{p}$.

18. Rance Ph. Epiphanius of Salamis and the Scotti: New Evidence for Late Roman - Irish Relations. Britannia, 2012, vol. 43, pp. 227-242.

19. Hilberg I. Sancti Eusebii Hieronymi Epistulae. Pars III: epistulae CXXI-CLIV. Vindobonnae, F. Tempsky, 1918. 368 p. (CSEL 56).

20. Sanctis D., de. Ancora sul padre dell'imperatore Teodosio. Ann N.S., ed. Rivista di Filologia e d'istruzuione classica, 1934, no. 12 (62), pp. 52-54.

21. Scharf R. Die Spätantike Truppe der Cimbriani. ZPE, 2001, vol. 135, pp. 179-184.

22. Speidel M.P. The Four Earliest Auxilia Palatina. REMA, 2004, vol. 1, pp. 133-146.

23. The Works of the Emperor Julian with an English Translation by W. C. Wright. Vol. I. London, William Heinemann, 1913.510 p.

24. Tougher Sh. Reading between the Lines: Julian's First Panegyric on Constantius II. Baker-Brian N., Tougher Sh. Emperor and Author: The Writings of Julian the Apostate. Swansea, The Classical Press of Wales, 2012, pp. 19-34.

25. Varady L. Pannonica Ergänzende Notizen zum letzten Jahrhundert. Bonner Jahrbücher, 1990, vol. 190, pp. 175-200.

\section{Information about the Author}

Evgeniy A. Mekhamadiev, Candidate of Sciences (History), Senior Lecturer, Department of Medieval History, Saint Petersburg State University, Universitetskaya naberezhnaya St., 7/9, 199034 Saint Petersburg, Russian Federation, e.mehamadiev@spbu.ru, https://orcid.org/0000-0003-1823-4588

\section{Информация об авторе}

Евгений Александрович Мехамадиев, кандидат исторических наук, старший преподаватель кафедры истории Средних веков, Санкт-Петербургский государственный университет, ул. Университетская набережная, 7/9, 199034 г. Санкт-Петербург, Российская Федерация, e.mehamadiev@spbu.ru, https://orcid.org/0000-0003-1823-4588 